\title{
Chapter 2 \\ The Bottom Line: Impacts of Alien Plant Invasions in Protected Areas
}

\author{
Llewellyn C. Foxcroft, Petr Pyšek, David M. Richardson, Jan Pergl, \\ and Philip E. Hulme
}

\begin{abstract}
Phrases like "invasive species pose significant threats to biodiversity..." are often used to justify studying and managing biological invasions. Most biologists agree that this is true and quantitative studies support this assertion. Protected areas are the foundation of conservation initiatives in many parts of the world, and are an essential component of an integrated approach to conserving biodiversity and the associated ecosystem services. The invasion of alien plants constitutes a
\end{abstract}

\section{L.C. Foxcroft $(\bowtie)$}

Conservation Services, South African National Parks, Private Bag X402, Skukuza 1350, South Africa

Centre for Invasion Biology, Department of Botany and Zoology, Stellenbosch University, Private Bag X1, Stellenbosch 7602, South Africa e-mail: Llewellyn.foxcroft@sanparks.org

\section{P. Pyšek}

Department of Invasion Ecology, Institute of Botany, Academy of Sciences of the Czech Republic, Průhonice CZ 252 43, Czech Republic

Department of Ecology, Faculty of Science, Charles University in Prague, CZ 12844 Viničná 7, Prague 2, Czech Republic

e-mail: pysek@ibot.cas.cz

D.M. Richardson

Centre for Invasion Biology, Department of Botany and Zoology,

Stellenbosch University, Private Bag X1, Stellenbosch 7602, South Africa e-mail: rich@sun.ac.za

\section{J. Pergl}

Department of Invasion Ecology, Institute of Botany, Academy of Sciences of the Czech Republic, Průhonice CZ 252 43, Czech Republic

e-mail: pergl@ibot.cas.cz

P.E. Hulme

The Bio-Protection Research Centre, Lincoln University, PO Box 84,

Canterbury, New Zealand

e-mail: Philip.hulme@lincoln.ac.nz 
substantial and growing threat to the ability of protected areas to provide this service. A large body of literature describes a range of impacts, but this has not been assessed within the context of protected areas. We do not aim to review the state of knowledge of impacts of invasive plants; rather, we collate examples of work that has been carried out in protected areas to identify important patterns, trends and generalities. We also discuss the outcomes of various studies that, while not necessarily undertaken in protected areas, are likely to become important for protected areas in the future. We discuss the range of impacts under five broad headings: (i) species and communities; (ii) ecosystem properties; (iii) biogeochemistry and ecosystem dynamics; (iv) ecosystem services; and (v) economic impacts.

Keywords Biogeochemistry - Conservation • Economic impact • Impact

- Management $\bullet$ Nature reserve

\subsection{Introduction: Why Are Impacts of Alien Plants in Protected Areas Especially Concerning?}

Phrases like "invasive species pose significant threats to biodiversity..." are frequently used to justify the study and management of biological invasions. Most biologists agree that this is true and quantitative studies support this assertion (see e.g. Vilà et al. 2011; Pyšek et al. 2012; Simberloff et al. 2013 for recent reviews). Most ecologists and environmental managers agree that the diversity of life is in serious decline (Pimm et al. 2001; Pereira et al. 2010; Rudd et al. 2011), with some indicating that we are witnessing one of the greatest extinction events in our planet's history (e.g. Novacek and Cleland 2001). Protected areas (PAs) are part of an approach to conserve biodiversity and slow its loss (Hansen et al. 2010). Indeed, in a survey of 93 terrestrial PAs in 22 tropical countries, protected areas were shown to be effective in halting problems such as land clearing, logging, hunting, unplanned fires and overgrazing (Bruner et al. 2001); unfortunately impacts of invasive alien species were not included in the study.

The invasion of alien plants in PAs poses a serious concern for one of the most pressing conservation initiatives globally. The intensity of research on impacts of invasive plants varies among regions (Hulme et al. 2013), but there are some notable cases, for example in Hawaii Volcanoes National Park, where a substantial body of literature exists (see Loope et al. 2014). In this chapter we do not attempt a comprehensive review of what is known about the impacts of invasive plants in general, as many extensive reviews have been carried out on, for example, impacts of invaders on species, communities and ecosystems (Pyšek et al. 2012), soil nutrient cycling (Ehrenfeld 2003), mechanisms underlying impacts (Levine et al. 2003), ecosystem carbon and nitrogen cycling (Liao et al. 2007), hybridisation (Vilà et al. 2000), competition (Vilà et al. 2004), plant reproductive mutualisms (Traveset and Richardson 2006) and ecosystem services (Vilà et al. 2010). Rather, we examine what has been done within PAs, or what is specifically pertinent to them, due to their unique and essential conservation role. 
Some studies have found that PAs contain fewer invasive species than their surrounds. A study of 184 PAs globally found about half the number of aliens inside the parks than outside (Lonsdale 1999). Similarly, across 302 nature reserves declared between 1838 and 1996 in the Czech Republic, significantly fewer alien species were found in the reserves (Pyšek et al. 2002). Further, the presence of intact natural vegetation appears to help slow the establishment of alien plants. A study examining the role of the boundary as a filter to alien plants in Kruger NP (South Africa) also showed that in areas where there was more than $90 \%$ natural vegetation within a $5 \mathrm{~km}$ radius of the park, alien plants were significantly less likely to invade (Foxcroft et al. 2011; Jarošík et al. 2011).

Opposite trends are unfortunately frequently reported, for example, showing that alien plants can invade natural areas that have not experienced anthropogenic disturbances (e.g. Gros Morne NP in boreal Canada; Rose and Hermanutz 2004). As early as the 1980s, the SCOPE (Scientific Committee on Problems of the Environment) programme on biological invasions reported 1,874 alien invasive vascular plants from 24 case studies of nature reserves globally (Usher 1988; Macdonald et al. 1989). In southern Africa, only seven out of 307 PA managers that responded to a survey were of the opinion that no alien species were known to occur in their reserve (Macdonald 1986). In a 1980 report to Congress in the USA, 300 national park service areas reported 602 perceived threats to natural resources involving alien plants and animals (see Houston and Schreiner 1995). At around the same time, at least 115 invasive alien plant species that threaten natural areas, parks and other protected lands had been identified in Virginia, USA (Heffernan 1998). A decade later a study reported 20,305 alien plant species infestations, with 3,756 unique alien plants, totalling 7.3 million ha in 218 national parks in the USA (Allen et al. 2009). A Global Invasive Species Programme report (De Poorter 2007) identified 487 PAs where invasive alien species were recorded as a threat. More than 250 wildlife refuges and 145 National Parks in the USA were shown to have been invaded by invasive alien species (De Poorter 2007). The Nature Conservancy indicated that of 974 of their projects globally, about $60 \%$ regard invasive alien plants to be the main threat (2009, unpublished data at http://conpro.tnc.org/ reportThreatCount). In the US national parks, $61 \%$ of 246 park managers indicated that alien plant invasions were moderate or major concerns (Randall 2011). An assessment of 110 PAs in South Africa's Ezemvelo KZN Wildlife conservation agency found that invasive alien plants represent the greatest threat to biodiversity in the province of KwaZulu-Natal (Goodman 2003). Based on results of an internet survey, it has recently been reported that managers of PAs in Europe perceive invasive species as the second greatest threat to their areas after habitat loss (Pyšek et al. 2014).

Without doubt, the threat, impact and management problems associated with alien plant invasions in PAs are increasingly being recognised as a major issue. Providing science-based evidence of the negative impacts of these invasions is becoming increasingly important in motivating for resources from frequently under-resourced conservation budgets. Protected areas face numerous challenges, including tourism-related issues, wildfire management, poaching and illegal 
harvesting of resources (Barber et al. 2004; Dudley et al. 2005; Alers et al. 2007), and climate change (Hannah et al. 2002; Huntley et al. 2011). Consequently, alien species control programmes must compete with these often emotive and charismatic management needs for resources. Managers often require evidence of potential problems within their area of concern and while localised empirical investigations can provide this information, collaboration across similar situations and systems can provide a much broader, synthetic understanding (Kueffer 2012).

Particular kinds of impacts are likely to be of more concern to different PAs than to other categories of land use, due to the specific objectives of PAs. Although the core function of many PAs is to conserve native 'biodiversity' in as natural a state as possible, the concept of 'biodiversity' is interpreted differently for different situations (Mayer 2006). Some PAs focus mainly on rare or single species protection, others on conservation of ecological processes, and yet others on landscapes, habitats or patch dynamics (Nott and Pimm 1997). Depending on the goal of the PA, where plant invasions threaten the specific entity of concern, different kinds of management approaches may be adopted. Outside PAs there is growing acceptance of the concept of 'novel ecosystems' which posits, among other things, that some ecosystems should be managed to ensure the continued delivery of particular services, irrespective of the composition of species in that system (native vs. alien) (Hobbs et al. 2006). This philosophy is unlikely to be widely adopted for PAs soon, except in very special cases, although tenets of the novel ecosystem philosophy will certainly be more widely discussed in general conservation forums in the future.

\subsection{Impacts of Alien Plant Invasions: Species, Ecosystems, Processes and Economics}

The search for general models for conceptualising and evaluating impacts of invasive alien species has been underway for many years. Early descriptions were mostly observational. For example Elton's widely acclaimed book, Ecology of invasions by animals and plants (Elton 1958), included many anecdotal observations. The SCOPE programme on nature reserves in the 1980s indicated that all case studies had examples of presumed effects of invasive species, but that it was difficult to clearly identify the cause of the observed impact (Usher 1988). Later, correlative approaches began being employed, comparing pre- and post-invasion sites, or sites with varying levels of abundance (for example, Parker and Reichard 1998). A generalised model for understanding ecological impacts (Parker et al. 1999) argued that the net impact of an invasive species should be conceptualised as the product of the geographic range of the invaders (area invaded), its abundance (density or biomass) and the per-capita or per-biomass effect. This model may provide PAs with a usable method for objectively assessing impacts of different species, especially where the distribution can be accurately 


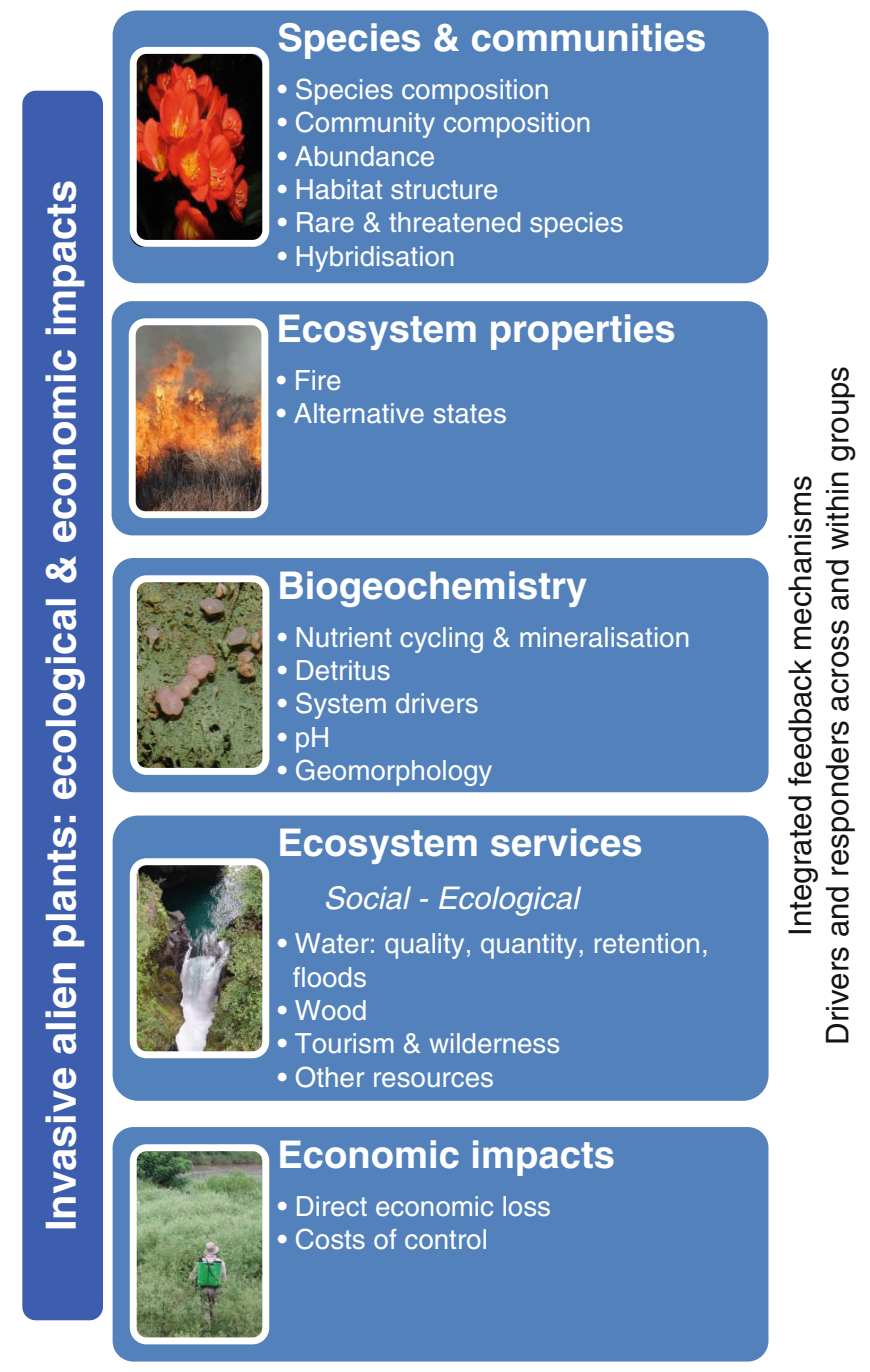

Fig. 2.1 Generalised outline of ecological and economic impacts of invasive alien plants in protected areas (Photos: Llewellyn C. Foxcroft, Navashni Govender (fire), Ezekiel Khoza (spraying of Parthenium hysterophorus))

mapped and abundance precisely estimated. Describing and quantifying the per-capita effect remains a challenge (Parker et al. 1999).

To avoid discussing the impacts of invasive plants as simply a list of examples, we used a general outline which clusters related issues (Fig. 2.1). The broad headings we use are (i) species and communities; (ii) ecosystem properties; (iii) biogeochemistry and ecosystem dynamics; (iv) ecosystem services; and (v) economic impacts. 


\subsubsection{Species and Communities}

Global indicators for IAS under the Convention on Biological Diversity's 2010 Biodiversity Target show that invasive species are causing a decline in species diversity of IUCN red-listed amphibians, birds and mammals (McGeoch et al. 2010). In an assessment of impacts on imperilled species in the USA, about $57 \%$ of 1,055 listed plants were threatened by alien species (Wilcove and Chen 1998). Although a number of such generalised lists indicate the threat from alien plant invasions to native species (e.g. Mauchamp 1997; Pimentel et al. 2000), there is still a shortage of quantitative data. Such information is particularly crucial for advising policy makers, as the value of conservation is currently predominantly measured by its ability to protect species richness (a common interpretation of 'biodiversity', Mayer 2006).

A review of about 150 studies provided a synthetic understanding of general mechanisms underlying the impacts on plant and animal community structure, nutrient cycling, hydrology and fire regimes (Levine et al. 2003). These authors found that many studies examined the impacts of invasions on plant diversity and composition, but fewer than $5 \%$ test whether these effects arise through competition, allelopathy, alteration of ecosystem variables or other processes. Nonetheless, competition was often hypothesised as a primary mechanism, and in nearly all studies alien plants exhibited strong competitive effects over native species. In contrast to studies of the impacts on plant community structure and higher trophic levels, research examining impacts on nitrogen cycling, hydrology and fire regimes is generally highly mechanistic, often driven by species-specific traits.

An early study that sought to quantify the impacts of alien plants in PAs was in Theodore Roosevelt Island Nature Preserve in Washington, DC, USA. Here two species of invasive vines were shown to inhibit the recruitment of native forest species (Thomas 1980). Lonicera japonica (Japanese honeysuckle) inhibited the reproduction of dominant forest trees such as Liriodendron tulipifera (tulip poplar), Prunus serotina (wild black cherry) and Ulmus americana (American elm). Hedera helix (English ivy) mainly inhibited the recruitment of herbaceous species. The smaller plants were suppressed, and even established forest trees were eventually killed through shading (Thomas 1980). Alien vine species may have advantages due to altered phenologies (e.g. evergreen vs. deciduous) and can often invade low light habitats (Gordon 1998). In this way, species with different life-forms can cause patches of native plants to collapse and be completely replaced, thereby altering, for example, community or species structure and light regimes (Gordon 1998). Floating species, such as Eichhornia crassipes (water hyacinth), native to north-western Argentina, can invade the total surface area of a waterway, completely preventing any light penetration (Ashton and Mitchell 1989). Eichhornia crassipes is one of the world's worst aquatic invaders, and has been reported to have invaded PAs in Asia, Australia, New Zealand, Africa, and the USA (De Poorter 2007). 
Biodiversity indicators, frequently using spiders or beetles, provide information on the presence of a set of other species in an area (McGeoch 1998) and are increasingly being used as proxies for quantifying impacts. In Hluhluwe-iMfolozi Game Reserve (South Africa), Chromolaena odorata (Siam weed) invasion altered native spider assemblages, with negative changes in abundance, diversity and estimated species richness. These changes were, however, reversed immediately following clearing (Mgobozi et al. 2008). In a similar study in Kruger NP, an assessment of the impact of Opuntia stricta (sour prickly pear) found that across a gradient of its density, species richness and species density for beetles and spiders did not change significantly (Robertson et al. 2011). Assemblages for spiders also did not differ across treatments, but beetle assemblages were significantly different. In South African National Parks as a whole, 663 alien plant species (813 alien species in total) have been recorded (Spear et al. 2011), but other than a few isolated projects, to date little work has been done on quantifying their impacts.

Impacts of invasive plants, primarily $C$. odorata, have also been reported on small and large mammals in Hluhluwe-iMfolozi GR (Dumalisile 2008). Small mammals showed both higher species richness and diversity in uninvaded sites compared to invaded sites, regardless of $C$. odorata density. Large mammals also decreased in richness and diversity as $C$. odorata invasion density increased. Invasive alien plants can also, perhaps unexpectedly, even threaten megaherbivores. For example, Kaziranga NP in India is a vital habitat for the world's largest population of the great one-horned rhinoceros (Rhinoceros unicornis). The rhino is dependent on grasslands, which have been invaded by Mimosa rubicaulis (Himalayan mimosa), M. diplotricha (giant sensitive plant) and Mikania micrantha (mile-a-minute weed), hampering the growth of native palatable grasses (Lahkar et al. 2011). In Kenya, Lantana camara (lantana) invasions reportedly impact on the habitat of Sable antelope (Hippotragus niger; Steinfeld et al. 2006). Nile crocodile (Crocodylus niloticus) nesting habitat and sex ratios may be altered by invasions of C. odorata in KwaZulu-Natal, South Africa, due to shading and cooling of nesting sites by $5.0-6.0^{\circ} \mathrm{C}$. This can result in a female-biased sex ratio, with potentially adverse consequences for the population (Leslie and Spotila 2001). The wetlands of Kakadu NP in Australia, a world heritage and Ramsar site, are renowned for their high diversity and numbers of water birds, and are under threat from Mimosa pigra (sensitive plant) and Urochloa mutica (para grass; Setterfield et al. 2014).

By 2000 , alien plants had invaded approximately 700,000 ha of US wildlife habitat per year (Babbitt 1998, as cited in Pimentel et al. 2000). In Great Smoky Mountains NP (USA) for example, 400 of the approximately 1,500 vascular plant species are alien, and 10 of these are currently displacing and threatening native plant species (Hiebert and Stubbendieck 1993). Overall, Hawaii is estimated to have lost about $8 \%$ of its native plant species, with an additional $29 \%$ still at risk (Loope 2004; Fig. 2.2).

Invasive plants can also contribute to an increased abundance of other invasive species, thus facilitating 'invasional meltdown' (sensu Simberloff and Von Holle 1999). In Hawaii Volcanoes NP, the widespread Morella (= Myrica) faya (faya tree) significantly increases the abundance of the alien insect Sophonia rufofascia (a leaf 


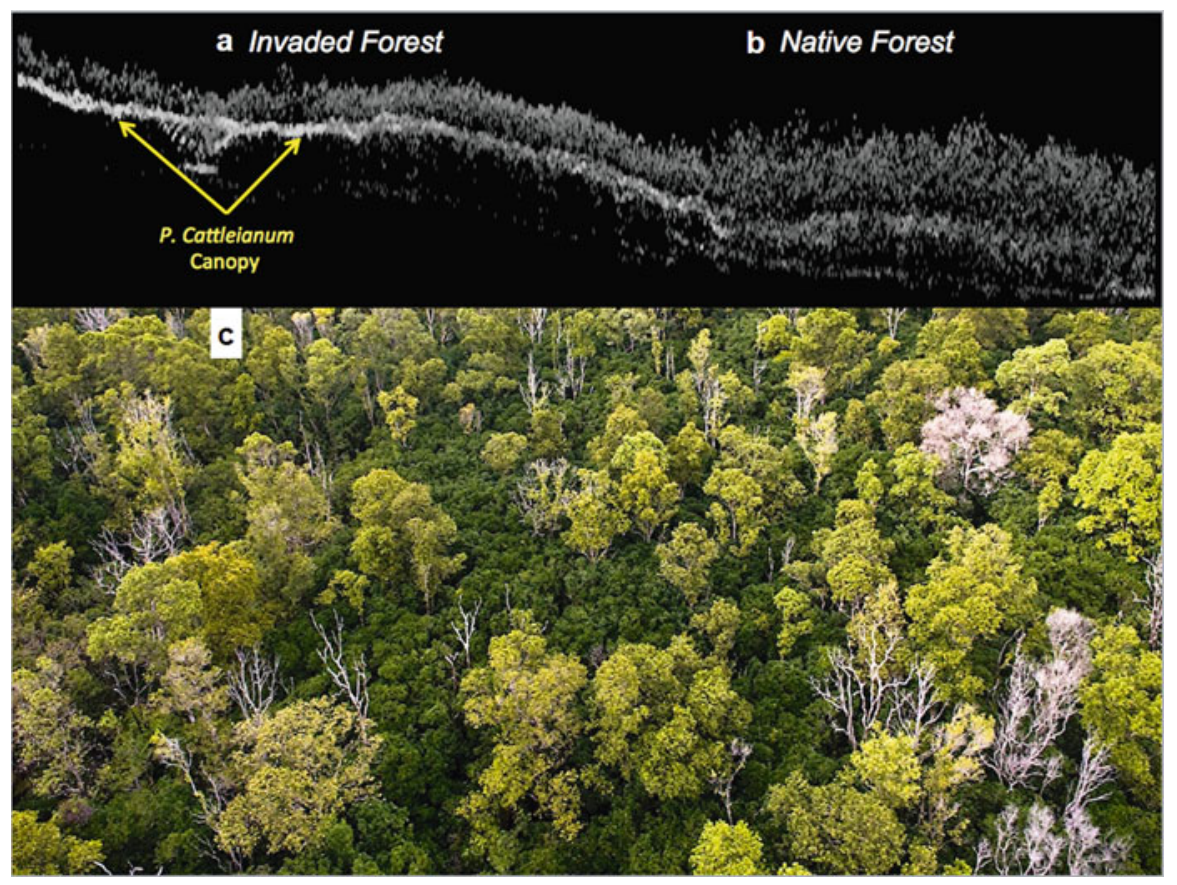

Fig. 2.2 Sectional structure of Psidium cattleianum invasion in Hawaiian lowland rainforest (a) with closed canopy of $P$. cattleianum within the forest (b) uninvaded forest (c) aerial view of $P$. cattleianum invasion (Figures: Gregory Asner, Carnegie Airborne Observatory, Carnegie Institution for Science)

phloem-feeding insect of Asian origin). In areas where $M$. faya is present the abundance of S. rufofascia was up to 19 times more abundant than in areas where M. faya had been removed (Lenz and Taylor 2001). This is of substantial concern as the diversity of host plants fed upon by $S$. rufofascia is extremely broad, encompassing over 300 species from 87 different families. Among these, 67 species are endemic or native to Hawaii, and 14 are either endangered or candidates for listing (Lenz and Taylor 2001).

The loss of genetic purity of a species is an important concern, especially for those rare and or threatened species which may face extinction, and have been given sanctuary in PAs. The hybridisation between alien and native species can lead to genetic swamping and loss of native species' genetic diversity. These risks are increased when a rare species hybridises with an abundant species, producing fertile offspring that can back-cross (introgress; Rhymer and Simberloff 1996). Invasive species may swamp native species through hybridisation. For example, the native species Hyacinthoides non-scripta (bluebell), an iconic species in the British Isles, is being threatened by its conger $H$. hispanica and its hybrid with the native Hyacinthoides $\times$ massartiana. Both the introduced and hybrid species are naturalised, and are frequently found within $1 \mathrm{~km}$ of $\mathrm{H}$. non-scripta (Kohn 
et al. 2009). Thus conservation programmes should strive to isolate rare species from cross-compatible congeners (Mooney and Cleland 2001).

Invasions can substantially influence plant reproductive mutualisms, while potentially disrupting mutualistic processes in invaded regions (Traveset and Richardson 2011). Good evidence exists for such impacts on pollination and reproductive success of native species (Traveset and Richardson 2011). For example, invasive plants that are highly attractive to pollinators can reduce overall visitation of native species (Morales and Traveset 2009; Gibson et al. 2012). These interactions can have consequences for whole communities due to the effects cascading through the network (Traveset and Richardson 2011). Such effects in PAs could be profound, by impacting directly on the biodiversity conservation objectives of the area.

Plant invasions have, to date, caused relatively few plant species to go extinct (Gurevitch and Padilla 2004; Sax and Gaines 2008). One reason for this is that, unlike the case with animal extinctions, plant extinctions can take decades or even centuries to play out (Gilbert and Levine 2013). However, plant invasions have led to the fragmentation of native plant communities worldwide, many of which currently survive as the 'living dead' (sensu Parker et al 1999, p. 12). This may be due to the persistence of native species in marginal habitats which, although still present, are reduced in abundance and distribution (Gilbert and Levine 2013). For example, serpentine soil landscapes in California include numerous rare and threatened plant species of high conservation concern. Invasions by European grasses impact on the area and quality of native species habitat, and may cause extinction hundreds of years after fully transforming the habitat (Gilbert and Levine 2013). Consequently, equating impact with numbers of absolute extinctions is misleading and inappropriate. Native species may still persist within an invaded area, but often be compromised or marginalised to such an extent that they no longer perform (to the same level, or at all) the functional roles they performed before they were affected by the invasive species (Wardle et al. 2011). Such changes are pervasive in ecosystems worldwide, and invasive plant species are increasingly prominent 'builders and shapers' of novel ecosystems in many regions (Richardson and Gaertner 2013). The examples discussed in this chapter show that invasive plant species very often drive ecosystems beyond thresholds at which ecological states are irreversibly altered. Such modified systems can sometimes be managed to deliver desired services, but such conditions are unacceptable in many PAs where the aim in to conserve species, community, structural and functional diversity.

\subsubsection{Ecosystem Properties: Changes in Fire Regime}

Ecosystems are the product of interactions between climatic conditions, resource availability and disturbance, of which the functional diversity of species is a major driver (Hooper et al. 2005). Biological invasions, often in concert with other global change drivers, have been shown in many cases to alter species diversity and 
community structure, thus having profound cascading effects on ecosystem functioning (Strayer 2012). The alternative states resulting from the relationship between invasive plants and fire, or the shading or smothering effect of vines and other species, are of some of the concerns facing PA managers, due in part to the irreversibility of such system changes.

Fire management has received substantial attention in PAs in many regions. This is because fire is a key driver of vegetation heterogeneity and patchiness in many systems, changing the structure, and relationships between trees and grasses (Bond et al. 2005), and acting as the primary diver of multiple ecosystem functions (Cole and Landres 1996; van Wilgen et al. 2003). Fire management has also attracted much attention because fire poses a hazard to infrastructure and human safety in PAs (e.g. Loehle 2004). Species, communities and even whole biomes have evolved with a particular tolerance to fire, including frequency, intensity, timing and vertical position (crown vs. ground). While the changing role of humans has received considerable attention in explaining and attempting to manage fire regimes generally (van Wilgen et al. 2003), increasing awareness is being given to changes in fire regimes, and consequently changes in ecosystem function, due to the widespread invasions of alien plants in many PAs.

Changes in fire regimes and ecosystem function due to invasions by alien plants have been documented from a range of habitats. One of the most frequently cited examples is related to the disruption of the grass-fire cycle (D'Antonio and Vitousek 1992). Invasive plants can increase vegetation flammability in areas where native species are poorly adapted and unable to cope in the presence of fire. In Hawaii Volcanoes NP at least one endangered plant and many of the dominant, poorly adapted, native species have been eliminated by fire (Hughes et al. 1991; D'Antonio and Vitousek 1992; Loope 2011). An increase in biomass of fine fuels can significantly increase the intensity or frequency of fires, or both. Introduced grasses that are fire adapted, or evolved in the presence of fire, are able to recover quickly after being burned, creating a positive feedback cycle that favours further invasion (D'Antonio and Vitousek 1992). In the Wildman Reserve in northern Australia, invasion of Andropogon gayanus (gamba grass) increased fuels loads by up to seven times, and increased fire intensity by up to eight times compared to areas with native grasses (Rossiter et al. 2003). Further, A. gayanus was shown to inhibit soil nitrification, thereby depleting total soil nitrogen from the already nitrogen-poor soils and promote fire mediated nitrogen loss (Rossiter-Rachor et al. 2009). Combined with the altered fire regime, it then forms self-perpetuating positive feedback loops (Rossiter-Rachor et al. 2009). In Kakadu NP, while Urochloa mutica produces dry season fuel loads similar to the native Hymenachne acutigluma (olive hymenchne), the fuel is drier and taller, increasing the fire intensity. Higher fire intensity and frequency may facilitate the displacement of $H$. acutigluma, which is fire sensitive, and damage other firesensitive woody vegetation (Setterfield et al. 2014).

In Mesa Verde NP (USA), successional pathways were altered following high intensity fires, with woodland-dominated systems being replaced by herbaceous species (Floyd-Hanna et al. 1993). Significant changes have been experienced in Dinosaur NP and Snake River Birds of Prey NP (USA), which have been invaded 


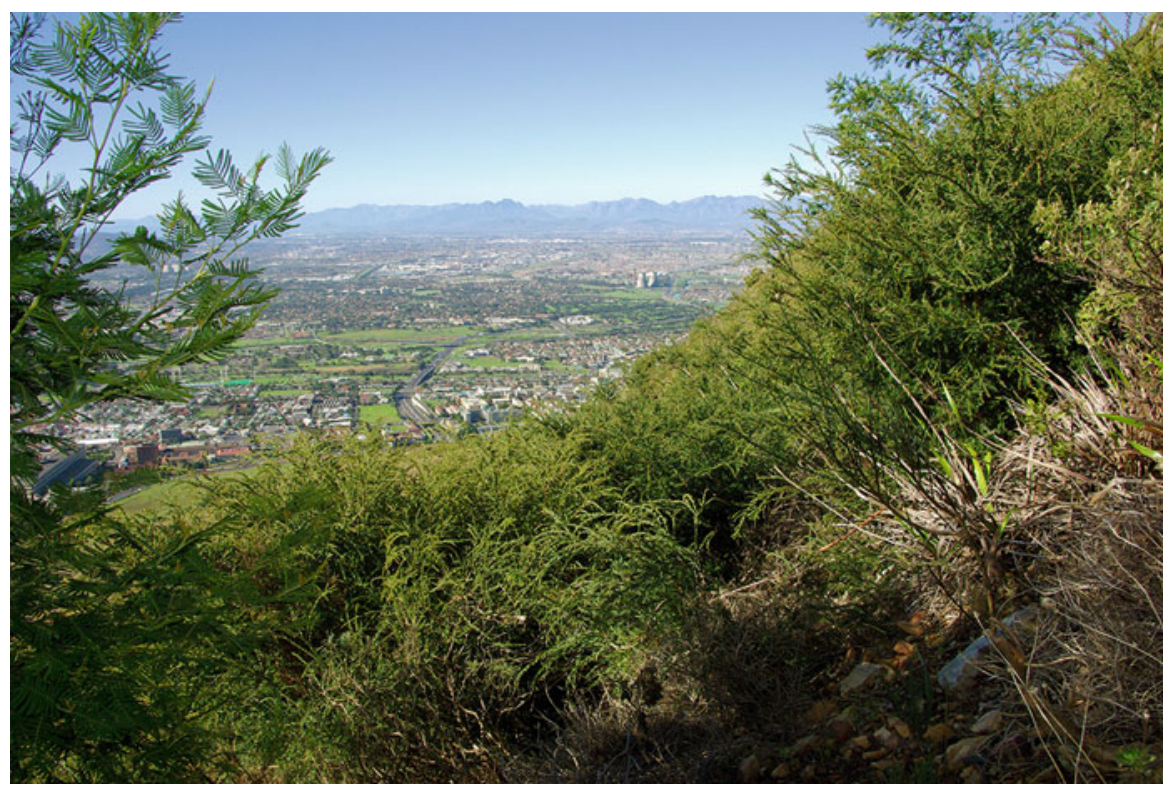

Fig. 2.3 Acacia paradoxa thickets in Table Mountain National Park (Photo Rafael D. Zenni)

by Bromus tectorum (cheatgrass). The fire frequency has been changed from one in 60-100 year, to three in 3-5 year return cycles, converting native shrublands to alien dominated grasslands (Randall 2011). In the Florida Everglades, marshlands with sedges, grasses and herbs have been replaced by Melaleuca quinquenervia (Australian paper bark), creating large stands of swamp forests with little or no herbaceous understory. Moreover, M. quinquenervia promotes crown fires, whereas the native plants have evolved with higher frequency, low intensity surface fires (Randall 2011). Another invasive plant that has caused major changes to the fire regime in the Everglades is Lygodium microphyllum (Old World climbing fern), a vine-like fern that climbs on trees and shrubs, forming mats that cause canopy trees to collapse. Fires that would normally stop at the edge of native cypress sloughs, travel up the 'fire ladders' provided by dry fronds of L. microphyllum to kill tree canopies (Schmitz et al. 1997).

Should fire regimes be changed significantly, species may become globally, locally or functionally extinct in a PA. In Table Mountain NP in South Africa's fynbos region, fire plays a key role in the maintenance of ecosystems, and native plants are adapted to the fire regime (Forsyth and van Wilgen 2008). However, the most common invasive species in the park, a suite of Australian Acacia (Fig. 2.3) and Hakea species, are also fire adapted, and their ability to produce large numbers of seeds facilitates their prolific spread after fires (van Wilgen et al. 2012). These trees and shrubs increase biomass and add to fuel loads, leading to increased fire intensity and erosion (van Wilgen and Scott 2001). Due to uncontrolled fires combined with the effects of plant invasions, 13 endemic plant species are known 
to have gone extinct since European colonization, with many more facing imminent extinction (Trinder-Smith et al. 1996).

Where invasive plants provide positive feedback systems to enhance habitat invasibility by altering, for example, nutrient cycling and fire frequency and intensity (Rossiter et al. 2003), alternative ecosystem states may emerge (Richardson and Gaertner 2013). The ability of an ecosystem to recover from such states or severe degradation depends on the extent of change to functional and structural properties (Brooks et al. 2010). The degree to which invasion and degradation change the biotic and abiotic threshold determines the level of intervention required to return the system to a state allowing natural regenerative process to function (Brooks et al. 2010). Whether active or passive restoration is necessary may depend on the nature of these legacy effects (Larios and Suding 2014). In PAs specifically, preventing degradation to the point where alternative states emerge, should be a high priority, not only to prevent compromising the area integrity, but also to allow the resilience of the system to recover following control (Jäger and Kowarik 2010). This is also important due the substantial costs likely to be associated with resource demanding active restoration programmes (in addition to costs for removal of the invader only).

\subsubsection{Biogeochemistry and Ecosystem Dynamics}

The ecosystem-level energy budget and biogeochemical cycling involve complex interactions of many facets at multiple spatial scales. These very interactions provide the ecosystem services on which humans depend for their existence (Sekercioglu 2010). Invasive alien plants are implicated in driving substantial changes to biogeochemical cycling and ecosystem dynamics (Ehrenfeld 2011), by altering components of the soil carbon, nitrogen, water and other ecosystem cycles (Ehrenfeld 2003). Invasive plant species have been shown to increase biomass, net primary productivity and nitrogen availability in many areas. Nitrogen fixation rates are altered and litter with higher decomposition rates than that of co-occurring native species is produced (Ehrenfeld 2003). However, the trends are not always clear. In a review of 56 invasive plants, variations across sites, and even opposite trends, were found (Ehrenfeld 2003; see also Hulme et al. 2013). While this work can be generalised across some PAs in similar settings, it appears that less work has been done on investigating the effects in PAs. Examining sitespecific cases not only contributes to a general understanding of invasion, but can provide detailed onsite information on the ecological integrity of a PA.

For example, in Hawaii Volcanoes NP, nitrogen-fixing species (Morella faya and $M$. cereifera) significantly increase soil nitrogen availability, by up to $400 \%$ (Vitousek et al. 1987). These changes resulted in altered plant succession trajectories, promoted increases in populations of alien earthworms, which in turn increased nitrogen burial rates, thereby further changing soil nutrient cycles (Randall 2011). In contrast, in northern Australia A. gayanus inhibits soil nitrification, thereby depleting total soil nitrogen from the already nitrogen-poor soils (Rossiter-Rachor 
et al. 2009). In Picayune Strand State Forest in Florida, Melaleuca quinquenervia significantly altered both above- and belowground ecosystem components (Martin et al. 2009). However, the detectability of impacts on the changes in ecosystem dynamics remains difficult. By the time these changes have increased to the level where they can be quantified, severe impacts are likely to have already occurred (Vilà et al. 2011), especially on plant species and communities. This will require a detailed, long-term monitoring programme to detect changes and determine trends.

\subsubsection{Ecosystem Services}

Ecosystem services are the benefits or the range of ecosystem functions, on which human livelihoods and wellbeing depend (Millennium Ecosystem Assessment 2005; Sekercioglu 2010). The impacts of invasive alien plants on ecosystem services is gaining much interest (Charles and Dukes 2007), and increasing efforts are being made to understand which ecosystem processes are being disrupted or altered by biological invasions.

The Millennium Ecosystem Assessment (2005) classified a number of potential services in four broad classes, including provisioning, regulating, supporting and cultural services. In brief, provisioning services are those tangible products obtained from ecosystems, including food, freshwater, fibre, fuel and genetic resources. Regulating services relate to the governing functions of ecosystems in order to provide other kinds of resources, such as water regulation (timing and extent of flooding, runoff, and others), water purification and waste treatment. Cultural services are non-material benefits, including spiritual or religious values, cultural heritage, recreation/tourism, aesthetic values, and wilderness or values of a sense of place (Mulongoy and Chape 2004). Supporting services are required for the continued maintenance of globally encompassing functions, which include photosynthesis, primary production, nutrient cycling, water cycling and soil formation. While interactions are multi-faceted and complex, the ecosystem services are delivered by different taxa or trophic levels (e.g. from soil micro-organisms, to vegetation, mammals, or whole communities) and can be assessed in a range of functional groups (e.g. populations, ecosystems, species, ecosystems; Sekercioglu 2010).

Protected areas, besides their roles in conserving individual species and their habitats, can be important for maintaining ecosystem function. These functions underlie much of the ability of ecosystems to provide services. For example, where whole or large portions of water catchment areas can be protected from invasions or managed when invaded, the lower impacts on overall ecosystem cycles will allow for improved delivery of water-related services. The Sabie-Sand river is one of the healthiest rivers in the Kruger NP. However, by 2002 about $23 \%$ of the upper catchment had been invaded to some degree, corresponding to a loss of about $9.4 \%$ of the rivers natural flow (Le Maitre et al. 2002).

There are a growing number of cases where the importance of PAs in providing and maintaining ecosystems services have been realised. Baekdudaegan Mountains 
Reserve, a unique forest protected area in Korea, explicitly aims to protect whole mountain ranges to maintain linkages, conserve biodiversity, sustain ecosystem services, and restore cultures and cultural values (IUCN 2009). Conservation planning frameworks are also beginning to be used to explore opportunities for aligning conservation goals for biodiversity with ecosystem services (Chan et al. 2006; Naidoo and Ricketts 2006).

\subsubsection{Economic Impacts}

Economic impacts are a crucial consideration in research on invasive alien species in general, and have been subject to intensive research in the last decade (e.g. Kasulo 2000; Pimentel et al. 2000; van Wilgen et al. 2008; Vilà et al. 2010). General studies on economic impacts by invasive alien species should provide compelling evidence for PA agencies as to the costs associated with inaction, and thus loss from resources as a result of invasion, and the costs associated with control, management or eradication. However, little work has been done on the economic costs of plant invasions in PAs specifically. This is probably because the situation in PAs is very different from other areas when it comes to economics. Because of the primary objective of PAs, which is most often to conserve biodiversity, standard economic models relating to production are often inappropriate.

For the above reason, economic assessments of plant invasions specifically related to PAs are scarce. However, some data are available from Europe. For example, the Czech regional offices for nature conservation of protected landscape areas spent about 1.8 million CZK ( US\$100,000) per year on the management and eradication of the most important invasive plant species (Linc 2012; Fig. 2.4). Removal and management costs of Prunus serotina in conservation areas in Germany are estimated to be $€ 149$ million (Reinhardt et al. 2003). The costs of controlling Rhododendron ponticum (rhododendron) invasion in the Snowdonia NP, Wales, was estimated to be $£ 45$ million (as at 2002; Gritten 1995; Pyšek et al. 2014).

In Kruger NP, between 1997 and 2011 the Working for Water programme spent about ZAR90 million ( US\$10.7 million, as at September 2012) on control efforts. In 2008 the control of alien plants within Table Mountain NP cost approximately ZAR9 million ( US\$1.08 million in 2008), with a focus of species of Acacia, Hakea and Pinus (Table Mountain National Park 2008). For the 2012-2013 financial year, the budgeted costs are approximately ZAR14 million (Table Mountain National Park US\$1.7 million in September 2012; Foxcroft et al. 2014).

A potentially significant problem, and one in dire need of detailed assessments, is the relationship between tourism and PAs. Protected areas rely, to varying extents, on the revenue provided by (eco-)tourism for their long-term sustainability. Eco-tourism and PA visitation generates a significant proportion of the economic income of many countries (Eagles et al. 2002). Understandably, the development of infrastructure for tourism in PAs is being strongly promoted. However, two challenges arise; (i) invasive alien plants can impact on tourism experiences in various 

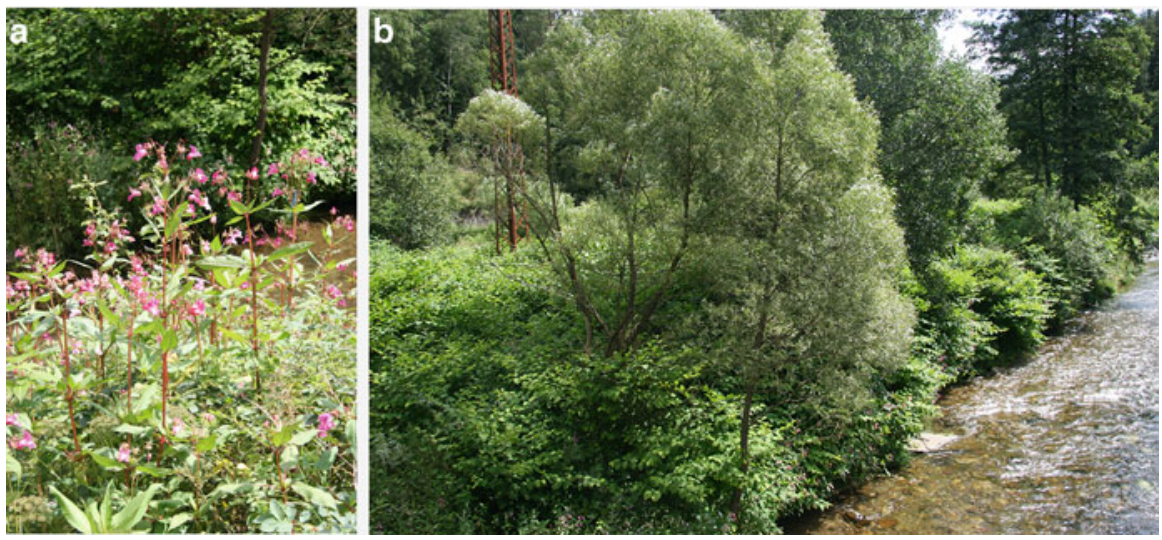

Fig. 2.4 (a) Impatiens glandulifera (Himalayan balsam) is an annual plant native to Asia, currently invasive in many protected areas in Europe (see Pyšek et al. 2014). Introduced as a garden ornamental and still frequently planted, it spreads into semi-natural plant communities along water courses (Photo Jan Pergl), and (b) one of the top ten invasive plant species in European protected areas (see Pyšek et al. 2014), the hybrid taxon Fallopia $\times$ bohemica is a noxious invader in riparian habitats where it forms extensive continuous populations extending over large sections of river shores and outcompetes native flora (Photo Jan Pergl)

ways, and (ii) increased tourism increases the likelihood of new introductions into PAs.

\subsection{Integration and Challenges}

The disparity between the needs and focus of PA managers and scientists and the complexity of managing multiple drivers of invasions are key challenges for the management of invasive alien plants in PAs.

Scientific research on biological invasions has grown exponentially over the last decade, but the relevance of much of the research for solving the immediate problems of policy makers and managers has been questioned (e.g. Esler et al. 2010). In Spain, for example, an assessment of environmental managers revealed the concern that not enough attention was being paid to developing costefficient management approaches (Andreu et al. 2009).

With the limited resources available, managers of PAs need to prioritise all types of activities that are required, including the prioritisation of various control options across many invasive taxa and invaded areas (Pyšek et al. 2014). This includes taxa with many types of impacts on different attributes of biodiversity. Invasive alien plants can also be passengers, or secondary factors that take advantage of habitat change. For example, in the Haleakala and Hawaii Volcanoes NPs feral pigs are recognised as a keystone introduced species, as they are the single major factor 
contributing to the spread of many introduced plants. They not only create open habitats through digging, but also transport propagules in their hair and faeces (Stone and Loope 1987). In a similar case in Pasoh Forest Reserve, an undisturbed tropical forest on the Malaysian peninsular, Clidemia hirta (Koster's curse), which was considered unlikely to invade and alter forest regeneration, utilised patches where light was made available and soil disturbed by wild pigs, for establishment (Peters 2001). In Forty Mile Scrub NP, Australia, about $73 \%$ of the dry rainforest and woodland savanna have been invaded with Lantana camara, with up to 5,000 individuals/ha being recorded (Fensham et al. 1994). It appears that root digging by pigs causes tree deaths, thereby allowing light penetration, which favours L. camara. The high level of invasion also causes substantially increased fuel loads and fires have killed canopy trees across a large area of the dry rainforest. In Gros Morne NP (Canada) moose (Alces alces), a non-native herbivore, appears to be the primary dispersal agents of alien plants, dispersing propagules and creating or prolonging disturbance by trampling (Rose and Hermanutz 2004).

The interaction of climate change and invasive alien plants is also becoming more concerning (see Dukes 2011 for a comprehensive review). One such concern is that the invasibility of habitats is likely to be increased. With the adaptability of introduced species to a wider range of climatic conditions, and the ability to rapidly exploit these changes, this may lead to an increase in distribution and abundance of invasive plants (Dukes 2011). There are a number of implications for PAs, with some suggesting that the impact may be greater in PAs than the broader landscape as the composition of species changes and vegetation types shift (e.g. Hannah et al. 2007; Gaston et al. 2008). While scientific models provide general recommendations, managers face the threats directly and are forced to develop and implement practical strategies, and thus need to be involved as collaborators in designing climate-change integrated conservation strategies (Hannah et al. 2002). One of the approaches recommend to enhance landscape connectivity between PAs against climate-change induced landscape and habitat shifts is implementing buffer zones around PAs, especially where conservation and compatible options are available (Hannah et al. 2002). However, many PAs already occur within a mosaic of highly transformed or disturbed landscapes, and heavily impacted areas can, for example, cause forest margins to retreat (Gascon et al. 2000), facilitating further invasions.

\subsection{Conclusions}

The range and severity of impacts of invasive plants in PAs is, in many areas, only starting to be realised. Examples of well documented impacts come from a few PAs, many of which are mentioned in this chapter. The extent of impacts are well documented for some of the best-studied PAs (e.g. Everglades NP and Hawaii Volcanoes NP, USA; Kakadu NP, Australia; Table Mountain NP, South Africa); these offer dire warnings that many types of invasive plants can cause many types 
of dramatic impacts. There is growing evidence that many other types of impacts are increasing in severity and extent in many other PAs; these include impacts that are driving the displacement of wildlife and changes to fire regimes, which undermine the justification for the existence of the PAs. More subtle effects of altered nutrient cycles and pollination and seed-dispersal networks are emerging more slowly, but will most likely result in significant and irreversible impacts.

Protected areas exclude different factors, to varying levels, extents and scales; this facilitates the examination of specific issues without the confounding effects that many factors associated with human dominated ecosystems typically bring to ecological studies. In the SCOPE programme (Usher et al. 1988) nature reserves were considered as useful outdoor laboratories where artificial impacts are minimised, and this is now even more important in a rapidly transforming world. While commendable efforts are being made to quantify the impacts in some PAs, improved knowledge transfer could certainly facilitate better uptake in management agendas worldwide. If PAs are to fulfil their role in the global conservation arena it is important that the mechanisms by which alien plant invasions degrade system attributes are understood, to enable appropriate response.

Acknowledgements LCF thanks South African National Parks for supporting work on this book and for general support. LCF and DMR thank the DST-NRF Centre of Excellence for Invasion Biology $(\mathrm{C} \cdot \mathrm{I} \cdot \mathrm{B})$, the National Research Foundation (South Africa) and Stellenbosch University for support. This work benefitted from financial support from the $\mathrm{C} \cdot \mathrm{I} \cdot \mathrm{B}$ and the Working for Water Programme through their collaborative research project on "Research for Integrated Management of Invasive Alien Species". PP was supported by long-term research development project no. RVO 67985939 (Academy of Sciences of the Czech Republic), institutional resources of Ministry of Education, Youth and Sports of the Czech Republic, and acknowledges the support by Praemium Academiae award from the Academy of Sciences of the Czech Republic. We thank Zuzana Sixtová for technical assistance.

\section{References}

Alers M, Bovarnick A, Boyle $\mathrm{T}$ et al (2007) Reducing threats to protected areas lessons from the field. A joint UNDP and World Bank GEF lessons learned study. The Worldbank, Washington, DC http://documents.worldbank.org/curated/en/2007/01/9532482/reducingthreats-protected-areas-lessons-field

Allen JA, Brown CS, Stohlgren TJ (2009) Non-native plant invasions of United States National Parks. Biol Invas 11:2195-2207

Andreu J, Vilà M, Hulme PE (2009) An assessment of stakeholder perceptions and management of alien plants in Spain. Environ Manag 43:1244-1255

Ashton P, Mitchell D (1989) Aquatic plants patters and modes of invasion, attributes of invading species and assessment of control programmes. In: Drake JA, Mooney H, di Castri F et al (eds) Biological invasions. A global perspective. Scope 37. Wiley, Chichester, pp 111-154

Barber CV, Miller KR, Boness M (eds) (2004) Securing protected areas in the face of global change: issues and strategies. IUCN, Gland/Cambridge

Bond WJ, Woodward FI, Midgley GF (2005) The global distribution of ecosystems in a world without fire. New Phytol 165:525-538 
Brooks KJ, Setterfield SA, Douglas MM (2010) Exotic grass invasions: applying a conceptual framework to the dynamics of degradation and restoration in Australia's tropical savannas. Restor Ecol 18:188-197

Bruner AG, Gullison RE, Rice RE et al (2001) Effectiveness of parks in protecting tropical biodiversity. Science 291:125-129

Chan KMA, Shaw MR, Cameron DR et al (2006) Conservation planning for ecosystem services. PLoS Biol 4:2138-2152

Charles H, Dukes JS (2007) Impacts of invasive species on ecosystem services. In: Nentwig W (ed) Biological invasions, vol 193. Ecological studies. Analysis and synthesis. Springer, Berlin/Heidelberg, pp 217-237

Cole DN, Landres PB (1996) Threats to wilderness ecosystems: impacts and research needs. Ecol Appl 6:168-184

D'Antonio CM, Vitousek PM (1992) Biological invasions by exotic grasses, the grass/fire cycle, and global change. Annu Rev Ecol Syst 23:63-87

De Poorter M (2007) Invasive alien species and protected areas: a scoping report. Part 1. Scoping the scale and nature of invasive alien species threats to protected areas, impediments to invasive alien species management and means to address those impediments. Global Invasive Species Programme, Invasive Species Specialist Group. http://www.issg.org/gisp_publica tions_reports.htm

Dudley N, Mulongoy KJ, Cohen S et al (2005) Towards effective protected area systems. An action guide to implement the convention on biological diversity programme of work on protected areas. Secretariat of the Convention on Biological Diversity, Montreal

Dukes JS (2011) Responses of invasive species to a changing climate and atmosphere. In: Richardson DM (ed) Fifty years of invasion ecology: the legacy of Charles Elton. WileyBlackwell, Oxford, pp 345-357

Dumalisile L (2008) The effects of Chromolaena odorata on mammalian biodiversity in Hluhluwe-iMfolozi Park. University of Pretoria, Pretoria

Eagles PFJ, McCool SF, Haynes CDA (2002) Sustainable tourism in protected areas: guidelines for planning and management. IUCN, Gland/Cambridge

Ehrenfeld JG (2003) Effects of exotic plant invasions on soil nutrient cycling processes. Ecosystems 6:503-523

Ehrenfeld JG (2011) Transformers. In: Simberloff D, Rejmánek M (eds) Encyclopaedia of biological invasions. University of California Press, Berkley/Los Angeles, pp 667-670

Elton CS (1958) The ecology of invasions by animals and plants. University of Chicago Press, Chicago

Esler KJ, Prozesky H, Sharma GP et al (2010) How wide is the "knowing-doing" gap in invasion biology? Biol Invas 12:4065-4075

Fensham RJ, Fairfax RJ, Cannell RJ (1994) The invasion of Lantana camara L. in Forty Mile Scrub National Park, North Queensland. Aust J Ecol 19:297-305

Floyd-Hanna L, Romme D, Kendall D et al (1993) Succession and biological invasion at Mesa Verde National Park. Park Sci 9:16-18

Forsyth GG, van Wilgen BW (2008) The recent fire history of the Table Mountain National Park and implications for fire management. Koedoe 50:3-9

Foxcroft LC, Jarošík V, Pyšek P et al (2011) Protected-area boundaries as filters of plant invasions. Conserv Biol 25:400-405

Foxcroft LC, Witt A, Lotter WD (2014) Chapter 7: Invasive alien plants in African protected areas. In: Foxcroft LC, Pyšek P, Richardson DM, Genovesi P (eds) Plant invasions in protected areas: patterns, problems and challenges. Springer, Dordrecht, pp 117-143

Gascon C, Williamson GB, Da Fonseca GAB (2000) Receding forest edges and vanishing reserves. Science 288:1356-1358

Gaston KJ, Jackson SF, Cantú-Salazar et al (2008) The ecological performance of protected areas. Annu Rev Ecol Evol Syst 39:93-113 
Gibson MR, Richardson DM, Pauw A (2012) Can floral traits predict an invasive plant's impact on native plant-pollinator communities? J Ecol 100:1216-1223

Gilbert B, Levine JM (2013) Plant invasions and extinction debts. Proc Natl Acad Sci USA 110:1744-1749

Goodman PS (2003) Assessing management effectiveness and setting priorities in protected areas in KwaZulu-Natal. BioScience 53:843-850

Gordon DR (1998) Effects of invasive, non-indigenous plant species on ecosystem processes: lessons from Florida. Ecol Appl 8:975-989

Gritten RH (1995) Rhododendron ponticum and some other invasive plants in the Snowdonia National Park. In: Pyšek P, Prach K, Rejmánek M et al (eds) Plant invasions: general aspects and special problems. SPB Academic Publishing, Amsterdam, pp 213-219

Gurevitch J, Padilla DK (2004) Are invasive species a major cause of extinctions? Trends Ecol Evol 19:470-474

Hannah L, Midgley GF, Millar D (2002) Climate change-integrated conservation strategies. Glob Ecol Biogeogr 11:485-495

Hannah L, Midgley GF, Andelman S et al (2007) Protected area needs in a changing climate. Front Ecol Environ 5:131-138

Hansen L, Hoffman J, Drews C et al (2010) Designing climate smart conservation: guidance and case studies. Conserv Biol 24:63-69

Heffernan KE (1998) Managing invasive alien plants in natural areas, parks, and small woodlands. Natural heritage technical report 98-25. Virginia Department of Conservation and Recreation, Division of Natural Heritage Program, Richmond, Virginia

Hiebert RD, Stubbendieck J (1993) Handbook for ranking exotic plants for management and control. U.S. Department of the Interior, National Park Service, Denver

Hobbs RJ, Arico S, Aronson J et al (2006) Novel ecosystems: theoretical and management aspects of the new ecological world order. Glob Ecol Biogeogr 15:1-7

Hooper DU, Chapin SF III, Ewel JJ et al (2005) Effects of biodiversity on ecosystem functioning: a consensus of current knowledge. Ecol Monogr 75:3-35

Houston DB, Schreiner EG (1995) Alien species in National Parks: drawing lines in space and time. Conserv Biol 9:204-209

Hughes F, Vitousek PM, Tunison T (1991) Alien grass invasion and fire in the seasonal submontane zone of Hawai'i. Ecology 72:743-746

Hulme PE, Pyšek P, Jarošík V et al (2013) Bias and error in current knowledge of plant invasions impacts. Trends Ecol Evol 28:212-218

Huntley B, Hole DG, Willis SG (2011) Assessing the effectiveness of a protected area network in the face of climatic change. In: Hodkinson TR, Jones MB, Waldren S et al (eds) Climate change, ecology and systematics. Cambridge University Press, Cambridge, pp 345-362

IUCN (2009) Proceedings of the international workshop on the future of the CBD programme of work on protected areas: Jeju Island, Republic of Korea, September 14-17, 2009. IUCN, Gland

Jäger H, Kowarik I (2010) Resilience of native plant community following manual control of invasive Cinchona pubescens in Galapagos. Restor Ecol 18:103-112

Jarošík V, Pyšek P, Foxcroft LC et al (2011) Predicting incursion of plant invaders into Kruger National Park, South Africa: the interplay of general drivers and species-specific factors. PLoS One 6:e28711

Kasulo V (2000) The impact of invasive species in African lakes. In: Perrings C, Williamson M, Dalmazzone S (eds) The economics of biological invasions. Edward Elgar, Cheltenham/ Northampton, pp 183-207

Kohn D, Hulme PE, Hollingsworth P et al (2009) Are native bluebells (Hyacinthoides non-scripta) at risk from alien congenerics? Evidence from distributions and co-occurrence in Scotland. Biol Conserv 142:61-74

Kueffer C (2012) The importance of collaborative learning and research among conservationists from different oceanic islands. Rev Écol (Terre Vie) 11:125-135 
Lahkar BP, Talukdar BK, Sarma P (2011) Invasive species in grassland habitat: an ecological threat to the greater one-horned rhino (Rhinoceros unicornis). Pachyderm 49:33-39

Larios L, Suding KN (2014) Chapter 28: Restoration within protected areas: when and how to intervene to manage plant invasions? In: Foxcroft LC, Pyšek P, Richardson DM, Genovesi $\mathrm{P}$ (eds) Plant invasions in protected areas: patterns, problems and challenges. Springer, Dordrecht, pp 621-639

Le Maitre DC, van Wilgen BW, Gelderblom CM et al (2002) Invasive alien trees and water resources in South Africa: case studies of the costs and benefits of management. For Ecol Manag 160:143-159

Lenz L, Taylor JA (2001) The influence of an invasive tree species (Myrica faya) on the abundance of an alien insect (Sophonia rufofascia) in Hawai'i Volcanoes National Park. Biol Conserv 102:301-307

Leslie AJ, Spotila JR (2001) Alien plant threatens Nile crocodile (Crocodylus niloticus) breeding in Lake St. Lucia, South Africa. Biol Conserv 98:347-355

Levine JM, Vilà M, D'Antonio CM et al (2003) Mechanisms underlying the impacts of exotic plant invasions. Proc R Soc Lond B 270:775-781

Liao C, Peng R, Luo Y et al (2007) Altered ecosystem carbon and nitrogen cycles by plant invasion: a meta-analysis. New Phytol 177:706-714

Linc O (2012) Efektivita likvidace invazních druhů v České republice na př́kladu bolševníku velkolepého [The efficiency of eradication of invasive species in the Czech Republic exemplified by Heracleum mantegazzianum]. BSc thesis, University of Economics, Prague

Loehle C (2004) Applying landscape principles to fire hazard reduction. For Ecol Manag 198:261-267

Lonsdale WM (1999) Global patterns of plant invasions and the concept of invasibility. Ecology 80:1522-1536

Loope LL (2004) The challenge of effectively addressing the threat of invasive species to the national park system. Park Sci 22:14-20

Loope LL (2011) Hawaiian Islands: invasions. In: Simberloff D, Rejmánek M (eds) Encyclopaedia of biological invasions. University of California Press, Berkley/Los Angeles, pp 309-319

Loope LL, Hughes RF, Meyer J-Y et al (2014) Chapter 15: Plant invasions in protected areas of tropical Pacific Islands, with special reference to Hawaii. In: Foxcroft LC, Pyšek P, Richardson $\mathrm{DM}$, Genovesi $\mathrm{P}$ (eds) Plant invasions in protected areas: patterns, problems and challenges. Springer, Dordrecht, pp 313-348

Macdonald IAW (1986) Invasive alien plants and their control in southern African nature reserves. In: Thomas LK (ed) Conference on science in the National Parks, vol 5. Management of exotic species in natural communities. Colorado State University, Fort Collins, pp 63-79

Macdonald IAW, Loope LL, Usher MB et al (1989) Wildlife conservation and the invasion of nature reserves by introduced species: a global perspective. In: Drake JA, Mooney H, di Castri $\mathrm{F}$ et al (eds) Biological invasions. A global perspective. Wiley, Chichester, pp 215-256

Martin MR, Tipping PW, Sickman JO (2009) Invasion by an exotic tree alters above and belowground ecosystem components. Biol Invas 11:1883-1894

Mauchamp A (1997) Threats from alien plant species in the Galápagos Islands. Conserv Biol 11:260-263

Mayer P (2006) Biodiversity: the appreciation of different thought styles and values helps to clarify the term. Restor Ecol 14:105-111

McGeoch MA (1998) The selection, testing and application of terrestrial insects as bioindicators. Biol Rev 73:181-201

McGeoch MA, Butchart SHM, Spear D et al (2010) Global indicators of biological invasion: species numbers, biodiversity impact and policy responses. Divers Distrib 16:95-108

Millennium Ecosystem Assessment (2005) Ecosystems and human well-being: biodiversity synthesis. World Resources Institute, Washington, DC 
Mgobozi MP, Somers MJ, Dippenaar-Schoeman AS (2008) Spider responses to alien plant invasion: the effect of short- and long-term Chromolaena odorata invasion and management. J Appl Ecol 45:1189-1197

Mooney HA, Cleland EE (2001) The evolutionary impact of invasive species. Proc Natl Acad Sci USA 98:5446-5451

Morales CL, Traveset A (2009) A meta-analysis of impacts of alien vs. native plants on pollinator visitation and reproductive success of co-flowering native plants. Ecol Lett 12:716-728

Mulongoy KJ, Chape SP (eds) (2004) Protected areas and biodiversity: an overview of key issues. CBD Secretariat/UNEP-WCMC, Montreal/Cambridge

Naidoo R, Ricketts TH (2006) Mapping the economic costs and benefits of conservation. PLoS Biol 4:2153-2164

Nott PM, Pimm SL (1997) The evaluation of biodiversity as a target for conservation. In: Pickett STA, Ostfeld RS, Shachak M (eds) The ecological basis of conservation. Heterogeneity, ecosystems, and biodiversity. Chapman and Hall, New York, pp 125-135

Novacek MJ, Cleland EE (2001) The current biodiversity extinction event: scenarios for mitigation and recovery. Proc Natl Acad Sci USA 98:5466-5470

Parker IM, Reichard SH (1998) Critical issues in invasion biology for conservation science. In: Fiedler PL, Kareiva PM (eds) Conservation biology for the coming decade. Chapman and Hall, London, pp 283-305

Parker IM, Simberloff D, Lonsdale WM et al (1999) Impact: towards a framework for understanding the ecological effects of invaders. Biol Invas 1:3-19

Pereira H, Leadley P, Proenca V et al (2010) Scenarios for global biodiversity in the 21st century. Science 330:1496-1501

Peters HA (2001) Clidemia hirta invasion at the Pasoh Forest Reserve: an unexpected plant invasion in an undisturbed tropical forest. Biotropica 33:60-68

Pimentel D, Lach L, Zuniga R et al (2000) Environmental and economic costs of nonindigenous species in the United States. BioScience 50:53-65

Pimm SL, Ayres M, Balmford A et al (2001) Can we defy nature's end? Science 293:2207-2208

Pyšek P, Jarošík V, Kučera T (2002) Patterns of invasion in temperate nature reserves. Biol Conserv 104:13-24

Pyšek P, Jarošík V, Hulme PE et al (2012) A global assessment of invasive plant impacts on resident species, communities and ecosystems: the interaction of impact measures, invading species' traits and environment. Glob Change Biol 18:1725-1737

Pyšek P, Genovesi P, Pergl J et al (2014) Chapter 11: Invasion of protected areas in Europe: an old continent facing new problems. In: Foxcroft LC, Pyšek P, Richardson DM, Genovesi P (eds) Plant invasions in protected areas: patterns, problems and challenges. Springer, Dordrecht, pp 209-240

Randall JM (2011) Protected areas. In: Simberloff D, Rejmánek M (eds) Encyclopaedia of biological invasions. University of California Press, Berkley/Los Angeles, pp 563-567

Reinhardt F, Herle M, Bastiansen F et al (2003) Economic impact of the spread of alien species in Germany. Report No. UBA-FB. Biological and Computer Sciences Division; Department of Ecology and Evolution, Frankfurt am Main

Rhymer JM, Simberloff D (1996) Extinction by hybridization and introgression. Annu Rev Ecol Syst 27:83-109

Richardson DM, Gaertner M (2013) Plant invasions as builders and shapers of novel ecosystems. In: Hobbs RJ, Higgs EC, Hall CM (eds) Novel ecosystems: intervening in the new ecological world order. Wiley-Blackwell, Oxford, pp 102-114

Robertson MP, Harris KR, Coetzee JA et al (2011) Assessing local scale impacts of Opuntia stricta (Cactaceae) invasion on beetle and spider diversity in Kruger National Park, South Africa. Afr Zool 46:205-223

Rose M, Hermanutz L (2004) Are boreal ecosystems susceptible to alien plant invasion? Evidence from protected areas. Oecologia 139:467-477 
Rossiter NA, Setterfield SA, Douglas MM et al (2003) Testing the grass-fire cycle: alien grass invasion in the tropical savannas of northern Australia. Divers Distrib 9:169-176

Rossiter-Rachor NA, Setterfield SA, Douglas MM et al (2009) Invasive Andropogon gayanus (gamba grass) is an ecosystem transformer of nitrogen relations in Australian savanna. Ecol Appl 19:1546-1560

Rudd MA, Beazley KF, Cooke SJ et al (2011) Generation of priority research questions to inform conservation policy and management at a national level. Conserv Biol 25:476-484

Sax DF, Gaines SD (2008) Species invasions and extinction: the future of native biodiversity on islands. Proc Natl Acad Sci USA 105:11490-11497

Schmitz D, Simberloff D, Hoffstetter R et al (1997) The ecological impact of non-indigenous plants. In: Simberloff D, Schmitz D, Brown T (eds) Strangers in paradise. Island Press, Washington, DC, pp 29-74

Sekercioglu CH (2010) Ecosystem services and functions. In: Sodhi NS, Erlich PR (eds) Conservation biology for all. Oxford University Press, Oxford, pp 45-67

Setterfield SA, Douglas MM, Petty AM et al (2014) Chapter 9: Invasive plants in the floodplains of Australia's Kakadu National Park. In: Foxcroft LC, Pyšek P, Richardson DM, Genovesi P (eds) Plant invasions in protected areas: patterns, problems and challenges. Springer, Dordrecht, pp 167-189

Simberloff D, Von Holle B (1999) Positive interactions of nonindigenous species: invasional meltdown? Biol Invas 1:21-32

Simberloff D, Martin J-L, Genovesi P et al (2013) Impacts of biological invasions: what's what and the way forward. Trends Ecol Evol 28:58-66

Spear D, McGeoch MA, Foxcroft LC et al (2011) Alien species in South Africa's National Parks. Koedoe 53:Art1032. doi:10.4102/koedoe. v53i1.1032

Steinfeld H, Gerber P, Wassenaar T et al (2006) Livestock's long shadow: environmental issues and options. Food and Agriculture Organization of the United Nations, Rome

Stone CP, Loope LL (1987) Reducing negative effects of introduced animals on native biotas in Hawaii: what is being done, what needs doing, and the role of National Parks. Environ Conserv $14: 245-258$

Strayer DL (2012) Eight questions about invasions and ecosystem functioning. Ecol Lett 15:1199-1210

Thomas LK (1980) The impact of three exotic plant species on a Potomac Island. National Park Service Scientific Monograph Series 13. U.S. Department of the Interior, Washington, DC, pp 1-179

Table Mountain National Park (2008) Park management plan. South African National Parks, Cape Town

Traveset A, Richardson DM (2006) Biological invasions as disruptors of plant reproductive mutualisms. Trends Ecol Evol 21:208-216

Traveset A, Richardson DM (2011) Mutualisms: key drivers of invasions... key casualties of invasions. In: Richardson DM (ed) Fifty years of invasion ecology: the legacy of Charles Elton. Wiley-Blackwell, Oxford, pp 143-160

Trinder-Smith TH, Cowling RM, Linder HP (1996) Profiling a besieged flora: endemic and threatened plants of the Cape Peninsula, South Africa. Biodiv Conserv 5:575-589

Usher MB (1988) Biological invasions of nature reserves: a search for generalizations. Biol Conserv 44:119-135

Usher MB, Kruger FJ, Macdonald IAW et al (1988) The ecology of biological invasions into nature reserves: an introduction. Biol Conserv 44:1-8

van Wilgen BW, Scott DF (2001) Managing fires on the Cape Peninsula: dealing with the inevitable. J Mediterr Ecol 2:197-208

van Wilgen B, Trollope WSW, Biggs HC et al (2003) Fire as a drive of ecosystem variability. In: du Toit JT, Rogers KH, Biggs HC (eds) The Kruger experience. Ecology and management of savanna heterogeneity. Island Press, Washington, DC, pp 149-170 
van Wilgen BW, Reyers B, Le Maitre DC et al (2008) A biome-scale assessment of the impact of invasive alien plants on ecosystem services in South Africa. J Environ Manag 89:336-349

van Wilgen BW, Forsyth GG, Prins P (2012) The management of fire-adapted ecosystems in an urban setting: the case of Table Mountain National Park, South Africa. Ecol Soc 17:8. doi: org/10.5751/ES-04526-170108

Vilà C, Weber E, D’Antonio CM (2000) Conservation implications of invasion by plant hybridization. Biol Invas 2:207-217

Vilà M, Williamson M, Lonsdale M (2004) Competition experiments on alien weeds with crops: lessons for measuring plant invasion impact? Biol Invas 6:59-69

Vilà M, Basnou C, Pyšek P et al (2010) How well do we understand the impacts of alien species on ecosystem services? A pan-European, cross-taxa assessment. Front Ecol Environ 8:135-144

Vilà M, Espinar JL, Hejda M et al (2011) Ecological impacts of invasive alien plants: a meta-analysis of their effects on species, communities and ecosystems. Ecol Lett 14:702-708

Vitousek PM, Walker LR, Whiteacre LD et al (1987) Biological invasion by Myrica faya alters ecosystem development in Hawaii. Science 238:802-804

Wardle DA, Bardgett RD, Callaway RM et al (2011) Terrestrial ecosystem responses to species gains and losses. Science 332:1273-1277

Wilcove DS, Chen LY (1998) Management costs for endangered species. Conserv Biol 12:1405-1407 